\title{
Fuel fractions obtained in the recycling of plastics
}

\author{
J. Sokołowski, G. Rokicki, M. Marczewski, J. Krajewska
}

Warsaw University of Technology, Faculty of Chemistry, ul. Noakowskiego 3, 00-664 Warszawa, Poland, e-mail: gabro@ch.pw.edu.pl

The decomposition of mixtures of polystyrene, polyethylene, and motor oil was studied at $470-510^{\circ} \mathrm{C}$ in a flow-through setup supplied with a fluidized bed reactor and a cascade of receivers. The aim of the work was to determine the role of the fluidized bed in the reactor, in the process of degradation of plastics in the cases where it was only a carrier of heat for the endothermal process of pyrolysis or it was both a carrier of heat and a catalytic bed for the process. The effect of the catalyst granulation and of the method of the organization of work in the reactor on the yield of the process and on the composition of the products obtained, was also studied.

In the cases where $\mathrm{Al}_{2} \mathrm{O}_{3}$ of granulation $0.2 \mathrm{~mm}$ was used as a fluidized bed catalyst the liquid products of the decomposition of the polymers contained mainly alkyl-aromatic derivatives of styrene, benzene and alkane hydrocarbons. If nano- $\mathrm{Al}_{2} \mathrm{O}_{3}$ was used as a catalyst and it was introduced into the reactor with a stream of raw materials, the obtained products were solids, composed mostly of styrene and alkene hydrocarbons.

Keywords: plastic recycling, catalytic cracking.

Presented at VII Conference Wasteless Technologies and Waste Management in Chemical Industry and Agriculture, Międzyzdroje, 12 - 15 June, 2007.

\section{INTRODUCTION}

A steady increase of consumption of plastics and still a low degree of their recycling lead to the accumulation of enormous amounts of wastes that must be disposed of in order to avoid a serious degradation of the natural environment.

Polyolefins and polystyrene are valuable polymers present in the wastes of plastics since the rupture of their chemical bonds may produce compounds suitable for reuse. Besides, thermoplastic polymers constituting more than $65 \%$ of the plastics produced, are used widely as packaging materials, hence they are the main components of waste plastics in communal wastes.

A recycling of waste plastics is an alternative to yard storage which presently covers only about $1.6 \%$ of the plastics produced. That process aiming at the transformation of waste polymers into useful hydrocarbons includes such methods as pyrolysis, gasification, cracking and catalytic hydrocracking ${ }^{1-2}$.

Both the pyrolysis and the cracking of polymers lead to the formation of hydrocarbon fractions rich in olefins and in aromatic compounds unsuitable for direct use. The amount of these compounds may be limited by subjecting the polymers to degradation in the process of catalytic hydrocracking. As another solution for the recycling of polyolefins it is possible to make use of thermal-catalytic degradation at $300-550^{\circ} \mathrm{C}$ under atmospheric pressure. The process results in the rupture of chemical bonds and produces free radicals of shorter hydrocarbon chain. The radicals undergo disproportioning to give saturated and unsaturated hydrocarbons of rather random chain length. Such a process is realized in the case of polyethylene. Thermal degradation of polystyrene usually gives styrene as the main product of depolymerization ${ }^{3}$.

A reasonable method for the processing of mixtures of polyolefins and polystyrene by catalytic cracking has been proposed at the Faculty of Chemistry of Warsaw University of Technology. Free radicals and unsaturated hydro- carbons obtained in the decomposition of polyethylene react with styrene or its oligomers to give liquid alkylaromatic fractions that can be used as components of engine fuels. The studies were used as a basis for developing a brief foredesign for a large laboratory scale installation.

At present investigations are being carried out to determine the role of the fluidized bed in the reactor in the process of degradation of plastics, the fluidized bed being regarded as:

- a carrier of heat for the endothermic process of pyrolysis and, at the same time, as a catalytic bed for the process,

- exclusively as a carrier of heat,

- a carrier of heat and a part of a catalyst.

A part of the studies has been devoted to the determination of the effect of granulation of the catalyst and of the organization of work inside the reactor on the yield of the process and on the composition of the products obtained.

Some results of the studies are presented in this paper.

\section{INTRODUCTION}

In former studies ${ }^{4}$ the fluidized bed played the traditional role of a carrier of heat, necessary for the decomposition of plastics and as a catalytic bed. The catalysts used were: aluminosilicates, aluminium oxide and zeolite HZSM-5 in mixtures with $\mathrm{SiO}_{2}$ (quartz sand). The amount of the catalyst in the bed varied from several per cent the bed behaved practically as an inert heat carrier, up to an equivalent mixture with quartz sand, to give a yield of more than $50 \%$ in the decomposition of plastics to a mixture of liquid aliphatic and aromatic hydrocarbons suitable for the direct blending of motor fuels.

For purely practical reasons commercial nitrogen was used as a fluidizing gas, and the linear velocity of the carrier gas and the granulation of the catalyst were selected so as to provide the bed movement (the bed was fountain-like) and not to allow to carry the catalyst grains 
away form the reactor, along with the cracking products. The linear velocity of nitrogen, as calculated for the empty reactor tube, was $0.43 \mathrm{~m} / \mathrm{min}$ at $20^{\circ} \mathrm{C}(2-5 \mathrm{~m} / \mathrm{min}$ in hot temperatures) and the grain size of the catalyst was 0.16 $-0.25 \mathrm{~mm}$.

Taking into account the particle size of the polymers intended for degradation one can assume that only the outer surface of the catalyst grains participates in the process of decomposition, irrespective of whether the grains are solid or porous. Under such an assumption the grain size becomes a key parameter characterizing the catalyst. Under technological conditions it is possible to mount e.g. rows of multicyclones working at increased temperatures and to reduce the granulation of the catalyst grains down to a fraction of a millimeter. For this reason an attempt was also made in these studies to evaluate the effect of the catalyst grain size on the yield of the process and the composition of the products by observing the behaviour of the system under very drastic changes in the granulation of the catalyst grains, from $200 \mu \mathrm{m}$, through $0.5 \mu \mathrm{m}$ down to $50 \mathrm{~nm}$.

Anticipating the problems in the execution of the experiments, connected with blowing tiny catalyst particles out of the reactor, a method of dosing the charge of raw materials was changed with a simultaneous change of the function played by the fluidized bed to the role of the heat carrier and partly of a catalyst. A mixture of polymers and the catalyst was introduced to the reactor in the form of the high viscosity liquid.

\section{EXPERIMENTAL}

\section{Work station}

Figure 1 presents a scheme, and Figure 2 shows a photograph of a set-up for thermal-catalytic cracking of polyolefins and polystyrene. A fluidized bed reactor of the capacity of $0.001 \mathrm{~m}^{3}$, with a catalyst layer of 0.0005 $\mathrm{m}^{3}$ volume at rest was an essential part of the set-up. Commercial nitrogen with the flow rate of $100 \mathrm{Nl} / \mathrm{h}$ served as the carrier gas, providing the bed fluidization. The reactor was heated by means of electric resistance coils, and the tests were performed at $470-510^{\circ} \mathrm{C}$. The degradation products were collected with the use of:

- five receptacles, four of which were cooled with tap water,

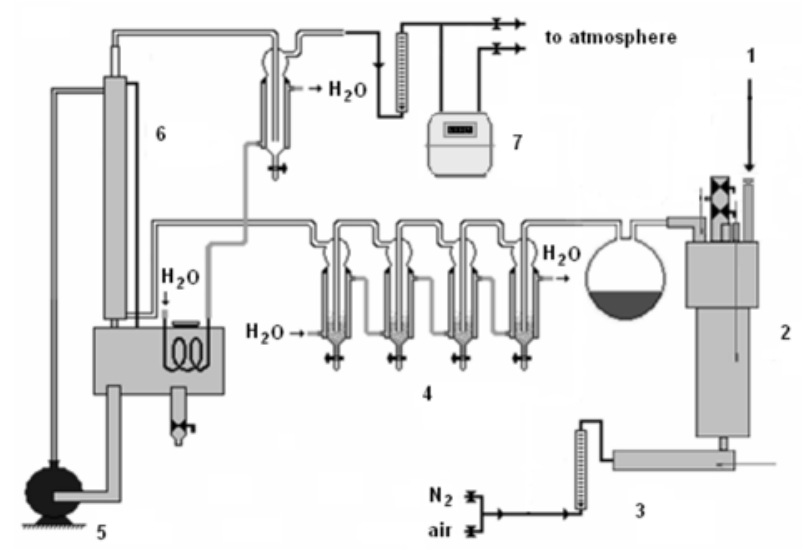

Figure 1. The scheme of the set-up: 1 - raw material, 2 - reactor, 3 - furnace, 4 - receptacles, 5 - pump, 6 - absorption column, 7 - gas meter
- absorption column sprinkled with a solution of the process products in extraction naphtha,

- additional water cooled dephlegmator was mounted on the outlet of the gases from the absorption column.

The flow rate of the gases delivered to the atmosphere was measured by means of a gas meter.

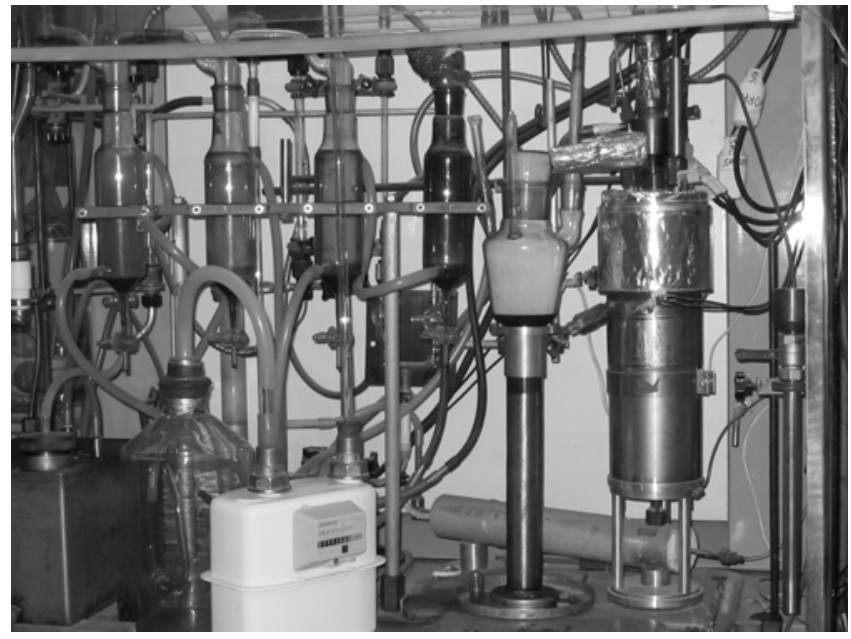

Figure 2. The phoptograph of the set-up

\section{Running conditions}

Thermal-catalytic degradation was carried out for (4:1) mixtures of commercial granulates of polyethylene and polystyrene with equal weight of motor oil. Prior to being introduced to the reactor the raw materials were melted and stirred by a mechanical stirrer in a specially built mixer. The obtained uniform mass was moulded into cylinders $0.1 \mathrm{~m}$ in height and $0.01 \mathrm{~m}$ in diameter, then dosed continuously, under constant load, into the reactor through a nozzle of the $3 \mathrm{~mm}$ diameter.

The following materials were used as the fluidized bed:

- inert silica bed (quartz sand of grain size $0.16-0.25$ $\mathrm{mm})$,

- $\mathrm{Al}_{2} \mathrm{O}_{3}$ supplied by Fluka (granulation $0.16-0.25$ $\mathrm{mm})$,

- nano- $\mathrm{Al}_{2} \mathrm{O}_{3}$ (particle size $45 \mathrm{~nm}$ ),

- mixtures of the above materials.

The compositions of the fluidized bed are shown in Table 1 along with the compositions of the samples of polymers degraded.

The catalyst included in the charge of plastics subjected to degradation was introduced at the stage of melting and mixing in the mixer.

Table 1. The compositions of the fluidized bed corresponding to appropriate samples of raw materials

\begin{tabular}{|l|l|}
\hline Composition of the fluidized bed & $\begin{array}{l}\text { Composition of raw } \\
\text { materials }\end{array}$ \\
\hline Oxide catalyst $\left(\mathrm{SiO}_{2}+\mathrm{Al}_{2} \mathrm{O}_{3}\right)$ & plastics + oil \\
\hline Oxide catalyst $\left(\mathrm{SiO}_{2}+\mathrm{Al}_{2} \mathrm{O}_{3}\right)$ & $\begin{array}{l}\text { plastics + oil + nano- } \\
\mathrm{Al}_{2} \mathrm{O}_{3}\end{array}$ \\
\hline $\begin{array}{l}\text { Oxide catalyst }\left(\mathrm{SiO}_{2}+\mathrm{Al}_{2} \mathrm{O}_{3}\right)+ \\
\text { nano- } \mathrm{Al}_{2} \mathrm{O}_{3}\end{array}$ & plastics + oil \\
\hline $\begin{array}{l}\text { oxide catalyst }\left(\mathrm{SiO}_{2}+\mathrm{Al}_{2} \mathrm{O}_{3}\right)+ \\
\text { nano- } \mathrm{Al}_{2} \mathrm{O}_{3}\end{array}$ & $\begin{array}{l}\text { plastics + oil + nano- } \\
\mathrm{Al}_{2} \mathrm{O}_{3}\end{array}$ \\
\hline $\mathrm{SiO}_{2}$ & $\begin{array}{l}\text { plastics + oil + nano- } \\
\mathrm{Al}_{2} \mathrm{O}_{3}\end{array}$ \\
\hline
\end{tabular}


Table 2. The conditions and results of the experiments in which $\mathrm{Al}_{2} \mathrm{O}_{3}$ and $\mathrm{SiO}_{2}$ oxides of granulation $0.16-0.25$ mm were used as both a catalyst and a carrier of heat for the process

\begin{tabular}{|c|c|c|c|c|c|}
\hline Test no. & Composition of fluidized bed & Raw material & $\begin{array}{l}\text { Temp. range in } \\
\text { reactor, }\left[{ }^{\circ} \mathrm{C}\right]\end{array}$ & \begin{tabular}{|c|}
$\begin{array}{c}\text { Yield of liquid product, } \\
{[\%]}\end{array}$ \\
\end{tabular} & Qualitative result \\
\hline 2.2 & $\begin{array}{l}\text { oxide catalyst }\left(50 \% \mathrm{Al}_{2} \mathrm{O}_{3}+50 \%\right. \\
\left.\mathrm{SiO}_{2}\right)\end{array}$ & PE + PS (4:1) + oil & $480-510$ & 51.8 & gas, liquid \\
\hline 2.4 & $\begin{array}{l}\text { oxide catalyst }\left(50 \% \mathrm{Al}_{2} \mathrm{O}_{3}+50 \%\right. \\
\left.\mathrm{SiO}_{2}\right)\end{array}$ & $\begin{array}{c}\mathrm{PE}+\mathrm{PS}(4: 1)+\text { oil }+ \\
1 \% \text { nano- }-\mathrm{Al}_{2} \mathrm{O}_{3}\end{array}$ & $480-510$ & 49.5 & gas, liquid \\
\hline 2.5 & $\begin{array}{l}\text { oxide catalyst }\left(50 \% \mathrm{Al}_{2} \mathrm{O}_{3}+50 \%\right. \\
\left.\qquad \mathrm{SiO}_{2}\right)\end{array}$ & $\begin{array}{c}\mathrm{PE}+\mathrm{PS}(4: 1)+\mathrm{oil}+ \\
2 \% \text { nano- } \mathrm{Al}_{2} \mathrm{O}_{3}\end{array}$ & $470-510$ & 50.8 & gas, liquid \\
\hline 2.6 & $\begin{array}{l}\text { oxide catalyst }\left(50 \% \mathrm{Al}_{2} \mathrm{O}_{3}+50 \%\right. \\
\left.\mathrm{SiO}_{2}\right)+ \text { nano- } \mathrm{Al}_{2} \mathrm{O}_{3}\end{array}$ & $\begin{array}{c}\mathrm{PE}+\mathrm{PS}(4: 1)+\text { oil + } \\
1 \% \text { nano- } \mathrm{Al}_{2} \mathrm{O}_{3}\end{array}$ & $470-490$ & 54.2 & gas, liquid \\
\hline 2.7 & $\begin{array}{l}\text { oxide catalyst }\left(50 \% \mathrm{Al}_{2} \mathrm{O}_{3}+50 \%\right. \\
\left.\qquad \mathrm{SiO}_{2}\right)+ \text { nano- } \mathrm{Al}_{2} \mathrm{O}_{3}\end{array}$ & $\begin{array}{l}\mathrm{PE}+\mathrm{PS}(4: 1)+\text { oil + } \\
2 \% \text { nano- } \mathrm{Al}_{2} \mathrm{O}_{3}\end{array}$ & $470-490$ & 49.0 & $\begin{array}{l}\text { gas, liquid, small } \\
\text { amount of solid } \\
\text { products }\end{array}$ \\
\hline 2.8 & $\begin{array}{l}\text { oxide catalyst }\left(50 \% \mathrm{Al}_{2} \mathrm{O}_{3}+50 \%\right. \\
\left.\qquad \mathrm{SiO}_{2}\right)+ \text { nano- } \mathrm{Al}_{2} \mathrm{O}_{3}\end{array}$ & $P E+P S(4: 1)+$ oil & $480-490$ & 55.8 & $\begin{array}{l}\text { gas, liquid, small } \\
\text { amount of solid } \\
\text { products }\end{array}$ \\
\hline
\end{tabular}

\section{Analysis of the products}

The chemical composition of the products of the transformation of polyethylene, polystyrene, motor oil and their mixtures was determined by means of gas chromatography (GC) using AGILENT 6980N chromatograph (with FID detector) with the capillary column HP5 of $30 \mathrm{~m}$ length, $0.32 \mathrm{~mm}$ in diameter and the film thickness of $0.25 \mu \mathrm{m}$.

The initial temperature: $70^{\circ} \mathrm{C}$, time $5 \mathrm{~min}$.

The rate of the temperature increase: $3^{\circ} \mathrm{C} / \mathrm{min}$.

The end temperature: $270^{\circ} \mathrm{C}$, time $40 \mathrm{~min}$.

A detailed identification of the transformation products was carried out basing on additional GC-MS measurements (gas chromatography coupled with mass spectrometry) using an analogous chromatographic column. In some cases the retention parameters were calibrated with the parameters of standards. In this way peaks of definite retention times were assigned to definite chemical compounds.

\section{RESULTS}

A number of tests on the decomposition of waste materials were performed. Some more interesting results divided into two groups of experiments, differing in the role of fluidized bed in the process, are shown in Tables $2-5$ and in Figures 3 and 4. Tables 2 and 3 and Figure 3 show qualitative and quantitative results of the tests in which the fluidized bed played the role of both the heat carrier and the catalyst of decomposition process. The granulation of the catalyst grains was $0.16-0.25 \mathrm{~mm}$ like in the former experiments ${ }^{4-5}$, but the bed contained also some additional amount of nano- $\mathrm{Al}_{2} \mathrm{O}_{3}(0.5 \%$ in the test 2.8 ), that have remained in the bed after some small amount of the catalyst nano-grains was introduced into the system along with the charge of raw materials.

Tables 4. and 5 and Figure 4 show the results of studies on degradation of a mixture of thermoplastic materials with oil in the presence of oxide catalyst of nominal size of $\mathrm{Al}_{2} \mathrm{O}_{3}$ grains $45 \mathrm{~nm}$. The catalyst was introduced to the system with the charge of raw materials, tests $3.1-3.4$. In these experiments the fluidized bed played only the role of a carrier of heat necessary for decomposition of the polymers. For the sake of comparison, in the test 3.5 nano- $\mathrm{Al}_{2} \mathrm{O}_{3}$ was introduced again into the fluidized bed thus restoring the role of the catalytic bed.
Table 3. The principal products of decomposition

\begin{tabular}{|c|c|c|c|c|}
\hline Test no. & \multicolumn{4}{|c|}{ Compound, \% share in products } \\
\hline & styrene & ethylbenzene & toluene & $\alpha$-methylstyrene \\
\hline 2.2 & 31.4 & 8.7 & 4.5 & 3.7 \\
\hline 2.4 & 28.2 & 15.3 & 5.6 & 4.1 \\
\hline 2.5 & 25.8 & 13.6 & 5.3 & 3.9 \\
\hline 2.6 & 30.0 & 9.7 & 5.0 & 4.1 \\
\hline 2.7 & 27.7 & 11.8 & 5.2 & 3.9 \\
\hline 2.8 & 28.2 & 12.8 & 5.1 & 4.2 \\
\hline
\end{tabular}

Composition of liquid fraction

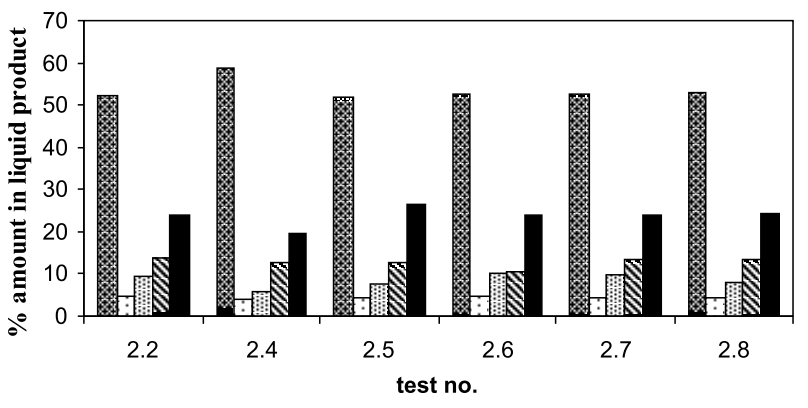

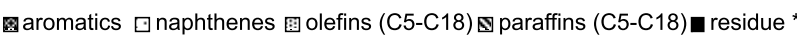

* a raw of compounds with a share in the product not exceeding $0.6 \%$

Figure 3. The composition of the liquid fraction and its share in the product obtained with oxide catalyst of granulation $0.16-0.25 \mathrm{~mm}$, acting also as a heat carrier

\section{Composition of solid fraction}

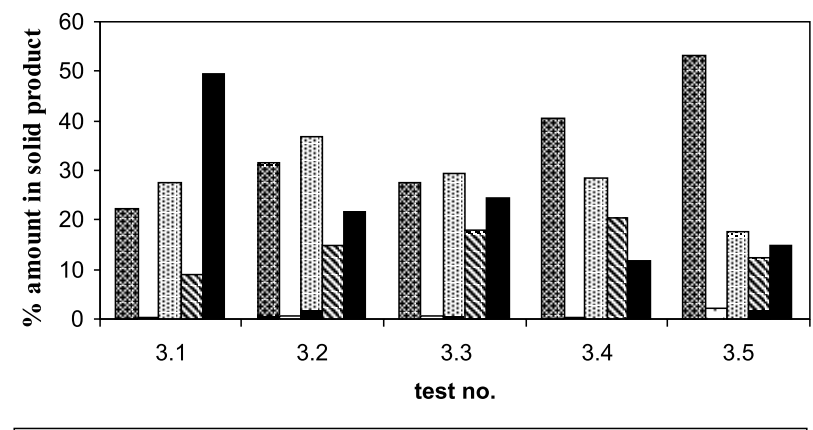

aromatics $\square$ naphthenes olefins (C8-C26) a paraffins (C8-C26) $\square$ residue *

* a raw of compounds with a share in the product not exceeding $0.6 \%$

Figure 4. The composition of the solid phase and its \% share in the product obtained with the nano- $\mathrm{Al}_{2} \mathrm{O}_{3}$ catalyst introduced into the reactor with the raw materials 
Table 4. The conditions and results of the experiments in which nano- $\mathrm{Al}_{2} \mathrm{O}_{3}$ was used as the catalyst

\begin{tabular}{|c|c|c|c|c|c|}
\hline Test no. & Composition of the fluidized bed & Raw material & $\begin{array}{c}\text { Range of temp. in } \\
\text { reactor, }\left[{ }^{\circ} \mathrm{C}\right]\end{array}$ & $\begin{array}{c}\text { Yield of solid product } \\
{[\%]}\end{array}$ & Qualitative result \\
\hline 3.1 & $\mathrm{SiO}_{2}$ & $\begin{array}{c}\mathrm{PE}+\mathrm{PS}(4: 1)+\text { oil }+ \\
1 \% \text { nano- } \mathrm{A}_{2} \mathrm{O}_{3}\end{array}$ & $500-530$ & 55.9 & gas, solid products \\
\hline 3.2 & $\mathrm{SiO}_{2}$ & $\begin{array}{c}\mathrm{PE}+\mathrm{PS}(4: 1)+\text { oil }+ \\
4 \% \text { nano- } \mathrm{Al}_{2} \mathrm{O}_{3}\end{array}$ & $470-500$ & 56.7 & gas, solid products \\
\hline 3.3 & $\mathrm{SiO}_{2}$ & $\begin{array}{c}\mathrm{PE}+\mathrm{PS}(4: 1)+\text { oil }+ \\
10 \% \text { nano- }-\mathrm{Al}_{2} \mathrm{O}_{3}\end{array}$ & $480-510$ & 64.5 & gas, solid products \\
\hline 3.4 & $\mathrm{SiO}_{2}$ & $\begin{array}{c}\mathrm{PE}+\mathrm{PS}(4: 1)+\text { oil }+ \\
20 \% \text { nano- } \mathrm{Al}_{2} \mathrm{O}_{3}\end{array}$ & $490-500$ & 73.3 & gas, solid products \\
\hline 3.5 & $\begin{array}{c}\text { oxide catalyst }\left(20 \% \mathrm{Al}_{2} \mathrm{O}_{3}+80 \%\right. \\
\left.\mathrm{SiO}_{2}\right)\end{array}$ & $\mathrm{PE}+\mathrm{PS}(4: 1)+$ olej & $480-500$ & 42.5 & gas, solid products \\
\hline
\end{tabular}

Table 5. The principal products of decomposition

\begin{tabular}{|c|c|c|c|c|c|}
\hline Test no. & \multicolumn{5}{|c|}{ Compound, \% share in products } \\
\hline & styrene & toluene & $\alpha$-methylstyrene & 1-decene & 1-undecene \\
\hline 3.1 & 15.5 & 1.3 & 1.7 & 1.9 & 1.8 \\
\hline 3.2 & 23.9 & 2.4 & 2.4 & 2.8 & 2.7 \\
\hline 3.3 & 19.9 & 2.0 & 2.0 & 2.2 & 0.6 \\
\hline 3.4 & 28.0 & 4.2 & 2.9 & 2.4 & 2.4 \\
\hline 3.5 & 33.3 & 4.8 & 3.4 & 2.1 & 2.2 \\
\hline
\end{tabular}

\section{SUMMARY AND CONCLUSIONS}

An analysis of the results presented shows a number of differences in the course of degradation of waste polymers depending on the role played by the fluidized bed and on the particle size of aluminium oxide catalyst used.

- An essential difference is related to the qualitative result of the process. A liquid fraction was the basic product in the experiments denoted as $2.2-2.8$, whereas in the tests nos. $3.1-3.5$ solid products were obtained.

- Another substantial difference is connected with the composition of the degradation products. The main products obtained in the tests $2.2-2.8$ were aromatic compounds: styrene, methylstyrene, and alkyl derivatives of benzene, and liquid linear hydrocarbons with 5-18 C atoms in a chain, mostly paraffins. On the other hand, tests $3.1-3.5$ gave mostly styrene with a small amount of its derivatives, derivatives of benzene, and solid linear hydrocarbons $\mathrm{C}_{8}-\mathrm{C}_{26}$ or longer, mostly of the olefinic series.

- A third noticeable difference is connected with the yield of the decomposition processes. In the experiments $2.2-2.8$ the yields of the liquid product are relatively high $(49-56 \%)$, and a small addition of nano- $\mathrm{Al}_{2} \mathrm{O}_{3}$ has no appreciable effect on the yield. In the tests $3.1-3.4$ the yields of decomposition producing a solid fraction are much higher, and one can observe an increase of the yield, from $56 \%$ to $73 \%$, on largely increasing the amount of catalyst in the system. A substantial difference in the yield of the process depends also on the method of introducing the catalyst, whether it is supplied with the raw materials or it is located in the fluidized bed (tests 3.4 and 3.5).

Taking into account the very great difference of the external surface of nano- $\mathrm{Al}_{2} \mathrm{O}_{3}$ and $\mathrm{Al}_{2} \mathrm{O}_{3}$ of granulation $0.16-0.25 \mathrm{~mm}$, as well as the specific properties of the nano-powders we anticipated that the yield of decomposition of the waste polymers should be higher in the cases where nano- $\mathrm{Al}_{2} \mathrm{O}_{3}$ is used as the catalyst, even if its content in the system is much smaller. Nobody could expect, however, that the product might be obtained in a form of a thick paste.
It appeared that the cause of phase differentiation of the decomposition products lies in different behaviour of the stream of raw material introduced into the reactor. The thermoplastic stream of a mixture of polyethylene with polystyrene and oil, eventually with a small $(1-2 \%)$ addition of nano- $\mathrm{Al}_{2} \mathrm{O}_{3}$ flows to the fluidized bed containing a catalyst $\left(50 \% \mathrm{SiO}_{2}+50 \% \mathrm{Al}_{2} \mathrm{O}_{3}\right)$, in the whole volume of which the polymer particles were decomposed and the products were synthesized. The vapours of the products were carried away, together with the carrier gas, to outer receptacles, where they condensed to give liquid products suitable for direct blending of gasoline. If a viscous stream of the mixture of raw material with nano$\mathrm{Al}_{2} \mathrm{O}_{3}$ in the amount of $4 \%$ or more was fed into the reactor, a part of the stream flew to the fluidized bed containing inert quartz sand, and the other part was decomposed before getting inside the bed. The product formed had a porous structure and composed of a mixture of nano-powders, unreacted raw materials, and residues of the products not yet carried away by the carrier gas outside the reactor. In the receptacles the degradation products were separated from the stream of carrier gas in the solid form. In the course of a single measurement test (3 $-4 \mathrm{~h}$ ) the porous barrier formed could cover practically the whole surface of the cylindrical part of the reactor. In such situation the time of the reaction of the raw materials was much shorter than that in the cases where the process proceeded within the whole volume of the fluidized bed. This was most probably the cause of breaking the particles of plastics into generally big fragments to form a solid phase.

The very high efficiency of the process, despite the short time of the raw materials staying in the reactor suggests another mechanism of breaking polyethylene particles than that dominating in the cases where the process proceeds in the whole volume of the fluidized bed. It is also a most probable reason why the reaction products contain so many of the unsaturated hydrocarbons.

The results of our studies have shown that mixtures of polyethylene and polystyrene undergo, in a fluidized bed reactor, various transformations leading to the creation of:

- liquid cracking products, if the fluidized bed contains an active oxide catalyst,

- solid cracking products, if the fluidized bed contains an inert heat carrier, and the catalyst (nano- $\mathrm{Al}_{2} \mathrm{O}_{3}$ ) is introduced into the reactor along with the raw materials,

- the transformations catalyzed by an oxide catalyst lead mostly to the formation of polystyrene and 
polyethylene cracking products. In the latter case saturated hydrocarbons dominate in the products,

- the transformations catalyzed by nano- $\mathrm{Al}_{2} \mathrm{O}_{3}$ lead mainly to polystyrene depolimerization products (styrene) and products of polyethylene cracking. In this case unsaturated hydrocarbons are the dominating fraction,

- the oxide catalyst catalyses probably the reactions of alkenes with the products of polystyrene decomposition, probably also their consecutive decomposition.

The role of nano- $\mathrm{Al}_{2} \mathrm{O}_{3}$ catalyst in the decomposition of polymers, the effect of reactor geometry and of the method of running the process on the yield of the reaction and on the composition of the products are still being investigated.

\section{LITERATURE CITED}

(1) Miskolczi N., Bartha L.: Gy. Deak, Polymer Degradation and Stability, 91, 2006, $517-526$.

(2) Aguado J., Serrano D.P., San Miguel G.: European trends in the feedstock recycling of plastic wastes. Global NEST Journal, 2006.

(3) Sarbak Z.: Kataliza w ochronie środowiska (Catalysis in environment protection), Wydawnictwo UAM, Poznań 2004.

(4) Sokołowski J., Rokicki G., Marczewski M., Baranowska M.: Ceramika 89, 2005, 86 - 94.

(5) Wrzosek M., Praca dyplomowa pt. „Badanie procesu katalitycznej degradacji odpadowych poliolefin i polistyrenu w reaktorze ze złożem fluidalnym” )Diploma work: Catalytic degradation of waste polyolefins and polystyrene in a fluidized bed reactor) P.W. Wydz. Chem., 2007. 